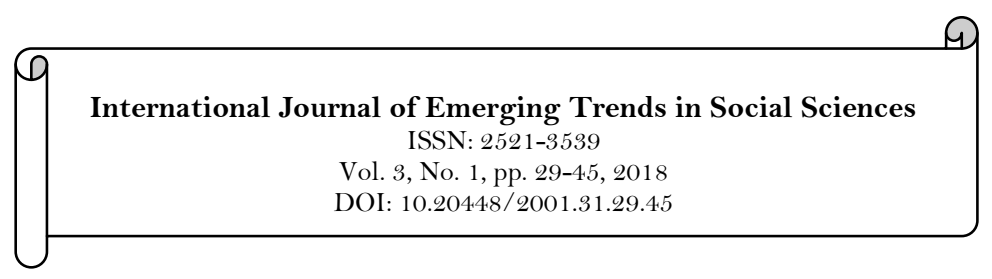

\title{
Transformative Constitutionalism in Post-Colonial Africa: A Framework for Democracy and Human Rights Protection
}

\author{
Eric Che Muma ${ }^{1}$ \\ ${ }^{1}$ Doctoral Candidate, Faculty of (Public and International) Law, Justus Liebig University, Giessen, Germany. \\ Email:meeteric2@yahoo.com
}

\begin{abstract}
The aftermath of World War II and the advent of independence in post-colonial Africa was marked by aspirations for constitutionalism, democracy, the rule of law, and human rights protection. With the arrival of independence, primarily in 1960, many African states discerned the need to draft new constitutions that ensured effective democracy, human rights protection, and the participation of citizens in the democratic process. Especially after 1990, when multi-party systems evolved in Africa, these constitutions have been subjected to several alterations and amendments. The changes appear to have heightened the desire of the people for a substantial transformation towards constitutionalism, democracy, and effective protection of human rights and fundamental liberties. Despite several amendments to some African constitutions, for instance, in Cameroon, these constitutions, if not all, have failed, to some extent, to attain the object of transformation and the peoples' aspiration for change. Some of the constitutions adopted were only superficially different from the provisions they had replaced. What remains questionable is whether constitutional amendments in most post-colonial African states can be perceived or described as having attained complete transformation despite the fact that they have not been able to ensure the object of constitutionalism, democracy, the rule of law, and effective protection of human rights and freedoms. The purpose of this paper is to critically analyse the concepts of constitutionalism and transformative constitutionalism as a framework for democracy and human rights protection in post-colonial Africa with specific focus on Cameroon in a comparative perspective. The paper also aims to ascertain whether African states with modern constitutions are necessarily transformative in nature despite the lack of effective protection of human rights and fundamental freedoms.
\end{abstract}

Keywords:

Transformative

Constitutionalism

Constitution

Transformation

Democracy

Rule of law

Human rights

Post-Colonial Africa.

Licensed:

This work is licensed under a

Creative Commons Attribution

4.0 License.

Publisher:

Scientific Publishing Institute

\section{Introduction}

After the horrors of World War II and the participation of some African states, colonial powers perceived the need to recompense African nations for their enormous contributions. ${ }^{1}$ The 1960 s marked the beginning of compensations with the according of independence. For instance, Cameroon, the Democratic Republic of Congo, Chad, Burkina Faso, Central African Republic, Ivory Coast, Togo were few amongst those who benefited from independence. ${ }^{2}$ As rightly described, the granting of independence to colonial African states was mere paperwork rather than an actual practice (Prempeh, 2007).

\footnotetext{
*Licence en Droit(Uni. of Yaounde), DIPL(Uni. Frankfurt, Germany), LL.M(Uni. Giessen \& Potchefstroom), Doctoral Candidate, Faculty of (Public and International) Law, Justus Liebig University, Giessen, Germany.

${ }_{1}^{1}$ Africa in general and Cameroon in particular had contributed enormously during World War II (1939-1945) supporting their colonial masters politically, economically, and socially. One of their greatest contributions included the supply of soldiers and raw materials to fight at the warfront. It should also be noted that Cameroon was purely a trust territory under the control of the British and the French before its independence in the $1960 \mathrm{~s}$ at the expense of Germany.

${ }^{2}$ See Democratic Republic of Congo 15 August 1960, Gabon 17 August 1960, Central African Republic 13 August 1960, Chad 11 August 1960, Burkina Faso 15 August 1960, Ivory Coast 7 August 1960, South Africa 1961 etc.
} 
This suggested that, even though Cameroon was granted independence in 1960, the sovereignty of the people was still being determined in Paris, not in Yaounde - the capital of Cameroon. Apart from these shortcomings, the post-colonial era was recognised by many African states as marking the beginning of selfdetermination in all spheres, including law, politics, economic and socio-cultural activities.

This period was also perceived as the beginning of transformation from French and British colonial legacy of civil law, indirect rule, and assimilation, as the case may be, to a new system of rule. Some African states produced new constitutions and numerous constitutional amendments.

Despite high expectations, the first constitutions of newly independent African states were generally identical to the constitutions of the former colonial powers ${ }^{3}$. In certain respects, these constitutions were dictatorial in nature and in line with the colonial doctrine of totalitarianism - one ruler with little or no guarantee of equal participation in the democratic process.

In a similar vein, even though with several constitutional amendments and reforms, African constitutions have attracted little or no interest from comparative constitutionalists. As noted by one constitutional scholar, 'most of the continent of Africa is usually overlooked, as if it were a legal 'Heart of Darkness,' as if it were a lawless world (Mary, 2003).

However, with the evolution of multi-party politics in Africa in the 1990s, the aspiration for a proper transformation toward constitutionalism, democracy, rule of law and human rights protection increased, proffering high hopes to citizens for greater and positive change. Mindful of the several constitutions and frequent constitutional reviews undergone by African states, it is uncertain whether this system of government and the present constitution has actually accomplished the transformative agenda. In an attempt to address this question, it will be appropriate for one to ascertain whether the Cameroon Constitution of 1996 has actually laid down a proper framework for transformation".

The object of this paper is to consider the concepts of Constitutionalism and Transformative Constitutionalism (hereinafter TC) in post-colonial Africa. The case of Cameroon will be analysed in line with South Africa and other African states with similar historical backgrounds.

It will examine whether the Cameroon Constitution, which has undergone several revisions, ideally serves as a persuasive example of TC in post-colonial Africa and a framework for democracy, rule of law and human rights protection. The aim here is not only to define constitutionalism and TC but also to analyse whether Cameroon can be guided by the experience in South Africa to understand the process of transformation in a different way that will bring about a significant transformation to the society.

The article argues that despite several constitutional amendments, Cameroon is yet to lay down a better framework for transformation that will satisfy the popular demand of the people.

The paper will take into consideration the challenges that impede complete or effective transformation in Cameroon and will suggest recommendations for the state under consideration. In a nutshell, the paper simply affirms that post-apartheid South African constitutional transformation can be used as a model to improve the Cameroonian Constitution or serve as a lesson.

\section{Constitutionalism and Transformative Constitutionalism in Post-Colonial Africa}

The existence of several constitutions in post-colonial African states appears to be the achievement of a long struggle for independence. While others were busy engaging in drafting new constitutions after the colonial era, many in Africa and Cameroon in particular perceived constitutional amendments as a framework for transformation towards constitutionalism.

Despite several constitutional changes since independence and after the introduction of multi-party politics in the 1990s, most constitutions in post-colonial Africa are still regarded as constitutions without Constitutionalism (Ndemesah, 2015). This may be due to the fact that most constitutions in post-colonial Africa in general and Cameroon in particular still lack the elements that contribute to constitutionalism. A simple understanding of the concepts of constitutionalism and TC in this context require us to, first of all, examine the concepts of constitution and constitutionalism and their significance in a state like Cameroon.

\footnotetext{
${ }^{3}$ See, for instance, the 1996 Constitution of the Republic of Cameroon, which still bears the carbon print in the 1958 Fifth French Gaullist Constitution of 1958. It should be noted that the 1958 Gaullist Constitution that was adopted under the leadership of General Charles Degualle was transformed into Cameroon's after she was granted independence by France. This Constitution, which was the first French Presidentialist's Constitution, has undergone several amendments, enhancing democracy, the rule of law, and human rights protection in France unlike the case in Cameroon.

${ }^{4}$ See the revised Constitution of the Republic of Cameroon, 1996. It is worth noting that since independence in 1960, Cameroon has so far received three Constitutions: 1960, 1972, and 1996 and numerous constitutional amendments: 1972, 1984, 1996, 2008. Its first and ever constitution was enacted on 1 st Janury 1960, immediately after independence under the leadership of late President Ahmadu Ahidjo, commonly referred to as the Constitution of the Federal Republic of Cameroon as amended in 1961, placing Cameroon under a federal system of Government. The second Constitution was adopted in 1972, which reunited French and British Cameroon under the canopy of the United Republic of Cameroon in a failed decentralized system of government. Few years after President Biya captured power in 1982, this constitution was partially revised in 1984 as a result of a coup d'état and subsequently, there was a full amendment in 1996 and in 2008. What is currently in place is the 1996 revised Constitution, which has undergone several amendments.
} 


\subsection{The Concepts of Constitution and Constitutionalism}

The word 'Constitution' is extremely influential, but more often than not, it is given a diverse meaning with similar objectives by constitutional law scholars in the Global South and the Global North. A constitution in the common legal parlance is the supreme law of a state and a framework that determines the functioning of every democratic society. ${ }^{5}$

It is also a grundnorm upon which all other laws derive their validity. It is the most important document of the state and determines or establishes the ground rules of government and protects certain fundamental rights (Gardbaum, 2012). Owing to changes in societies and globalisation in constitutional law, an important understanding of the concepts of constitutionalism and TC demand us to mention that constitutions are either rigid or flexible. Most early post-colonial constitutions adopted by African states were said to be non-liberal democratic in nature; whereas the post-1990 constitutions are said to be liberal democratic and liberal nondemocratic in nature.(Dieter, 2012).

It is, of course, apparent that prior to the development of modern constitutionalism, constitutions had existed before, but they were fashioned to describe the state of a country. These ancient constitutions were not out to limit pre-existing power but to create power out of the powerless. Presently, a constitution has become the primary law that shapes the desire and aspiration of citizens in every state.

A 'constitution', according to the Oxford Advanced Learner's Dictionary, is the system of laws and basic principles that govern a state, a country, or an organization (Wehmeier, 2000).

As noted by Black's, a constitution is the fundamental and organic law of a nation or state, establishing the conception, character, and organization of its government, as well as prescribing the extent of its sovereign power and the manner of its exercise.(Garner, 2001) in relation to this, as Ndobe also emphasizes, a constitution is the most important legal document for a nation, which subscribes to the rule of law because it defines the relationship between the citizens and the government.(Nkumbe, 2011).

However, far from being a document that contains a lifeless museum piece, a constitution is a living document that must be designed in such a way that it reflects as well as embodies the fears, hopes, aspirations, and desires of its people.(Fombad, 2007).

Despite different scholarly opinion as to the term, a constitution is employed to identify fundamental institutional arrangements, mostly but not always dealing with the distribution of political power that is more entrenched than ordinary law.(Tushnet, 2012).

A comprehensible understanding of the meaning of 'constitution' reveals that Cameroon's constitution is among the few African constitutions that merely reinforce the pre-1990 system of lone power, and many of the introduced token changes that reflect open and participatory democracy has never been implemented.

This seems to have made the concept of constitutionalism impossible in Cameroon. Constitutionalism is apparently a part and parcel of constitutional and democratic theory (Manga, 2002). While constitutionalism, like democracy, has no precise meaning in legal language, Gregor, for instance, holds that,

'In the context of political theory, "Constitutionalism" often signifies concern with the problem of how the institutions of a state are to be organised in order to secure the basic rights of men or citizens (Gregor, 1988).

Gregor's idea of constitutionalism appears very narrow in the sense of modern constitutionalism. This may be so because the concept is not just limited to the protection of human rights, and it may be questionable whether 'men' should be understood as excluding 'women'. In a more succinct language, Maschele (Rapatsa, 2014) opines that constitutionalism is premised on framing the constitution as the supreme law and the creation of institutional structures to control political power in the interest of all citizens.

It also guides in determining the extent to which human rights protection exists, the nature of limitations, how state organs operate, and how state officials should exercise and execute public functions. Its basis is to convey that state power is defined and subject to restrictions by law to protect civilians. In fact, it is not clear what African constitutionalism comprises of.

In Africa, the notion of African constitutionalism has not always led to positive experiences; it often leads to a one-party rule, lifelong presidencies, abuse of power, outright military dictatorships, and the denial and suppression of individual human rights by the authority assumed on behalf of the collectiveness or by virtue of higher state interests (Wiechers, 2010).

In the broadest term, Michel holds that 'modern constitutionalism requires imposing limits on the powers of government, adherence to the rule of law, and the protection of fundamental rights.'(Rosenfeld, 1994).

As noted by Charles, the concept at present encompasses the idea that a government should not only be sufficiently limited in a way that protects its citizens from arbitrary rule, but also that such a government should be able to operate efficiently and in a way that it can be effectively compelled to operate within its constitutional limits (Fombad, 2007).

${ }^{5}$ Marbury v Madison 5 U.S. 137[1803]; The State v Makwanyane [1995] (3) SA 391, para. 7 
The modern concept of constitutionalism, however, also rests on the recognition and preservation of human rights and fundamental freedoms, the separation of powers, an independent judiciary, review of the constitutionality of laws, the control of the amendment of the constitution, and the institutions that support democracy.(Fombad, 2011).

In the concept of identity, diversity, and constitutionalism, Francis Deng notes that modern constitutionalism entails 'more positive action to promote human dignity to the fullest possible extent'.(Francis, 2008). This implies that the achievement of constitutionalism rests on a certain number of preconditions, such as limiting governmental powers, separation of powers, and enhancing equal participation in the democratic process. In addition to modern Constitutionalism, Mahomed $C J$ in $S v$ Makwayane \& Others [supra] observed that a Constitution,

$\therefore$. represents a decisive break from, and a ringing rejection of, that part of the past which is disgracefully racist, authoritarian, insular, and repressive and a vigorous identification of and commitment to a democratic, universalistic, caring and aspirationally egalitarian ethos, expressly articulated in the Constitution.'6

According to Mahomed $C J$, modern constitutionalism aims at guaranteeing fundamental human principles based on human rights, egalitarianism, and dignity for all without distinction. It also requires states to change their negative approaches for doing things towards a positive direction, moving from an authoritarian regime to one of equal participation.

This is an example of 'transformative' constitutionalism, designed to make a fresh or new start and repudiate discredited past values and practices by including founding values and structural principles whose interpretation requires a normative approach (Goldsworthy, 2012). As Hailbronne rightly said, if there is a concept that embraces the ideal of constitutions as society's new political and moral foundation, this concept is transformative constitutionalism.'(Hailbronne, 2016).

Through the idea of moral foundation, what is meant is the incorporation of substantive state duties to work towards a more just society into constitutional law. Having understood the sundry opinions towards constitutionalism and modern constitutionalism, an interesting question that may be raised by many is whether the Cameroon Constitution depicts an example of transformative constitutionalism in post-colonial Africa. To demonstrate whether this is true or not draws our attention to the notion of TC.

\subsection{Transformative Constitutionalism}

These two concepts, 'transformation' and 'constitutionalism' are distinct from each other, considering the aspiration and fundamental values of the constitution. Even though not subject to universally accepted definitions, 'transformation' is a notion that connotes 'change' (Githiru, 2012).

In this case, this implies a change in the legal direction or order, interpretative approach, the approach and conduct of matters of the state, just to name a few. 'Constitutionalism' refers to the doctrine that governs the legitimacy of governmental action. ${ }^{7}$ The notion of transformative constitutionalism is drawn from several proponents such as Langa and Klare. Pius Langa $J$ simply defines this concept as follows:

a historic bridge between the past of a deeply divided society characterized by strife,

conflict, untold suffering, and injustice, and a future founded on the recognition of human

rights, democracy and peaceful co-existence and development opportunities for all . . .

irrespective of colour, race, class belief or sex (Langa, 2006).

Such changes include guaranteeing rights and the realisation of civil and political rights, socio-economic rights, and ensuring that there exist institutions safeguarding a comprehensive realisation of such rights. For Chaskalson $P$, TC would be a hollow ring if it fails to meaningfully effect change with regard to addressing these aspects and the people's aspirations. ${ }^{8}$ Indeed, by TC, Klare formulated a noble theory, which I found most appropriate:

a long-term project of constitutional enactment, interpretation, and enforcement committed ... to transforming a country's political and social institutions and power relationships in a democratic, participatory, and egalitarian direction (Klare, 1998).

According to Karl, the constitution endeavours to create a society that is entirely different from the past in terms of the relationship between the law, public institutions, and people. These definitions represent the goals of a modern society through the instrumentality of TC.

It is also an enterprise of inducing large-scale social change through nonviolent political processes firmly established in law. Presently, any attempt to change or amend a state's constitution should follow suit. Still, the question arises how one may refer to the 1996 Cameroon's constitution as an example of a TC that is still plagued with dictatorship less concerned about the interests of its nationals in political participation, victimisation, marginalisation, and ineffective entrenchment or protection of fundamental human rights despite several successful amendments.

\footnotetext{
${ }_{6}^{6}$ S v Makwanyane \& Others [1995] (3) SA 391, para. 262.

${ }^{7}$ Maschele Rapatsa (n 18) 890.

${ }^{8}$ Chief Justice Chaskalson in Soobramoney $v$ Minister of Health, Kwazulu-Natal (1998) 1SA 765(CC), 199712

BCLR 1696(CC), para.8.
} 
Arguably, the post-1990 constitutional reforms in Africa, Cameroon in particular, were expected to provide a new framework for dealing with dictatorship, repression, political instability, human rights violations, corruption, mismanagement of state property, and poverty - all of which had hindered progress on the continent since the independence movement (Fombad, 2011).

Charles for one, asserts that the 1996 constitutional amendment has regrettably resulted in a 'new' constitutional dispensation that is essentially negative, defensive, and a mere protective obfuscation of the status quo ante, and to this extent, is really at odds with modern constitutional trends in Africa and the rest of the world, which have tried to promote more participatory, accountable, and transparent constitutional governance (Fombad, 1998).

Transformation, in this sense, does not only imply changes in the legal order but also the fulfilment of fundamental rights and freedoms, equal enjoyment in practice of the rights and freedoms that are promised by the constitution, and the provision of greater access to education and opportunities through the various state mechanisms, including affirmative action measures (Langa, 2006).

Transformation is a permanent ideal - a way of looking at the world - that creates a space in which dialogue and contestation are truly possible, where new ways of being are constantly explored and created, accepted and rejected, and in which, change is unpredictable but the idea of change is constant. ${ }^{9}$ This is a perspective that discerns the constitution as transformative since it envisions a society that will always be open to change and contestation, a society that will always be defined by transformation.

A clear understanding of the concept of TC in this context, therefore, requires us to demonstrate whether, mindful of the several constitutional amendments in Cameroon, the 1996 Constitution portrays a framework for democracy, the rule of law, and human rights protection in post-colonial Africa.

\section{The 1996 Constitution: A Framework for Democracy and Human Rights Protection}

This section attempts to answer the question whether the Cameroon constitution truly represents an example of TC and serves as a framework for democracy, the rule of law, and human rights protection in postcolonial Africa, taking into consideration the fact that it has undergone several amendments. According to the African Charter on democracy and governance, all African states cognizant of their historical and cultural conditions have committed themselves to promote democracy, the rule of law, and human rights. ${ }^{10}$

Although, some changes in the constitution after 1990 seem to have delivered its promise of transformative aspiration for liberation, democratic change, the rule of law, and human rights protection; other revisions are still faced with the problem of liberation to achieving full democracy and human rights protection.

An interesting question that arises at this juncture is whether Cameroon's revised constitution has laid down a proper framework for democracy, rule of law, and human rights protection.

Although the tenor of Section 1(2)(3) of the constitution appears to have acknowledged these fundamental principles as founding values of the constitution, ${ }^{11}$ which, to the best of my knowledge, is short of complete appreciation. An attempt to tackle this question requires one to critically examine democracy, rule of law, and human rights as important components of constitutionalism in Cameroon, and whether they are being enjoyed by individual citizens both in law and in practice as promised by the constitution.

\subsection{Democracy}

The question of democracy within post-colonial African constitutions has been greeted with apathy. For many African politicians and legal scholars, democracy is a Western concept imposed on traditional African constitutionalism (Wiechers, 2010).

Perhaps, this might be so, since ancient Greece is the birthplace of democracy. ${ }^{12}$ However, it is absurd to think in such a negative direction. I strongly hold that a constitutional law scholar in the twenty-first century will not be one-sided in his or her perception towards democracy, cognizant of globalisation, the internationalisation of constitutional law, and the universality of human rights law in particular.

Of course, such thoughts could only come from uninformed African politicians who often escape from responsibility and accountability and lack an insight of African constitutional history. Since the early 1990s, the wave of democratisation has been increasingly spreading across Africa.

The long struggle for democracy in Africa is beginning to yield results, as the continent is overcoming a legacy of authoritarianism and apathy to democratic culture.

\footnotetext{
${ }^{9}$ Ibid. 354.

${ }^{10}$ Art. 4 of the African Charter on Democracy, Elections, and Governance, adopted in Addis Ababa May 2004 but not ratified by Cameroon; See also recital 3 of the Preamble to the UDHR; 1948 .

${ }^{11}$ Section $1(2)(3)$ states that the Republic of Cameroon shall be one and indivisible, secular, democratic and dedicated to social services and shall recognize and protect traditional values that conform to democratic principles, human rights, and the law.

${ }_{12}$ The word democracy was derived from the Greek words demos which means 'the people', and kratios which means 'power/kratien which means 'to rule'. This means a governance system by the people for the people, as opposed to the rule by one despot (autocracy) or a few.
} 
A critical understanding of a constitution will attest that the constitutional protection of rights can secure democratic government by protecting those rights that are a part of the concept of democracy itself. Since ancient Greece, the concept of democracy has remained elusive.

In the context of TC, democracy actually requires that some rights, for instance political participation, are placed beyond the control of the majority. Hilary Charlesworth in criticizing purely procedural concepts of democracy forwards the argument this way: 'A richer understanding of democracy involves acknowledging that there are some rights that are so basic to human dignity that they should be taken out of the political arena and given special protection'(Hilary, 2002).

As rightly said, without effective guarantee of civil liberties, elections do not constitute democracy, and a procedural minimum for defining democracy must include not only elections but reasonably broad guarantees of basic civil rights, such as freedom of speech/expression, association, assembly, and political participation, which provide the choice for the electorate to select candidates through a free and fair elections; civil and political liberties enable citizens to express themselves without fear of punishment (Fayemi, 2009).

This is clearly affirmed by the United Nations Development Programme(hereinafter UNDP), which states that, in democracies, people have a voice underpinned by freedom of speech and thought, freedom of information, free and independent media, and open political debate that allows them to be heard in public policy-making (United Nations Development Programme, 2002). Notably, in Sv Makwanyane, Paul Sieghart opines that,

' $[\mathrm{T}]$ he hallmarks of a democratic society are pluralism, tolerance, and broad-mindedness.

That although individual's interests must on occasion be subordinated to those of a group, democracy does not mean that the views of a majority must always prevail: a balance must be achieved which ensures the fair and proper treatment of minorities and avoids any abuse of a dominant position.' 13

From a positive standpoint, I strongly endorse Paul's argument, since democracy is best assured if people, individuals, or citizens are given equal protection and treatment both in rights and in law. However, in Cameroon, the situation seems to be the opposite; English Speaking Cameroonians (Anglophones), who make up $20 \%$ of the Cameroonian population as opposed to $80 \%$ of their French-speaking counterparts (Francophone's), are currently faced with discrimination and marginalisation in terms of employment, language, education, and protection from the law despite constitutional affirmation. ${ }^{14}$

In a democratic system of government, citizens participate freely in public debate that is able to extract the need to protect autonomy in this sphere from that system of government (Robert Post, 1993).

A closer look at the 1996 revised constitution affirms that the constitution advocates democratic principles such as democracy, secularity, fundamental human rights, the rule of law, separation of powers, judicial independence, and multi-party system and regular elections. ${ }^{15}$ Does this necessarily imply Cameroon is a true democratic society, which ensures democracy, rule of law, and human rights protection? An attempt to disentangle this question is short of appreciation. According to Ismail Mahomed CJ,

" $[\mathrm{t}]$ he realisation of this promising future cannot, however, be guaranteed by the eloquence of the Constitution. . . . It needs inter alia the widespread dissemination of a pervading human rights culture to support the values and institutions of the Constitution; organs of civil society active in its defence; media emphatic to its objectives; a vigilant Bar ready to identify transgressions of the Constitution to ventilate more specific issues arising from its more generalised aspirations, and to bring the discipline of the law and the scholarship of the international community to bear on their solution; academic inputs to bring vision and perspective to the debate; and a judiciary sensitive to and knowledgeable on such issues." 16

In fact, what Mahomed implies is that the values and institutions of the constitution should constantly and carefully be defended; citizens should be given the right to express their opinions in a democratic manner free from suppression in order to ensure a constant certainty. This is essential for safeguarding legality and legitimacy of the constitution.

Notwithstanding the lack of a universal and binding definition of democracy and the difficulty of application of this concept in post-colonial Africa, CT requires some level or degree of precision- or certainty sustaining-constitutionalism or democratic values. As submitted, similar to the words constitution and constitutionalism, democracy is an indeterminate word that has been subjected to a variety of tendentious interpretations (Fombad, 2007).

\footnotetext{
${ }^{13}$ S v Makwanyane (n 8) 369.

${ }^{14}$ See Art.1(3) of the 1996 Constitution, which states that the official languages shall be English and French, yet French dominates the entire administrative offices. An Attempt of the Civil Law system to override the Common Law system in the two English speaking regions (North West and South West Regions) is a very good example; it led to an uprising of the present crisis in the country since October 2016-emphasis added.

${ }^{15}$ See Preamble to the Constitution of 1996 and sections 1(2)(3), 2, and 37 of the constitution.

${ }^{16}$ Former Chief Justice Ismail Mahomed, 'The Namibian Constitution: Reconciling Legality and Legitimacy' (n 19) 52.
} 
Abraham Lincoln's now conventional definition of democracy - 'the government of the people, by the people and for the people' - has led to the popular view that democracy is a form of government (Abraham, 2013).

This definition gives no indication of the specific structure - be it political or economic - of a democratic society. At the World Conference on Human Rights, democracy was regarded by states as based on the freely expressed will of the people to determine their own political, economic, social, and cultural systems with their full participation in all aspects of their lives. ${ }^{17}$

In addition, in a remark to the Ghanaian parliament, President Obama mentioned that each nation gives life to democracy in its own way and in line with its own traditions. However, history offers a clear verdict: Governments respecting the will of their own people, governing by consent and not by coercion, are more prosperous, stable, and more successful than governments that do not. ${ }^{18}$

As noted by Obama, democracy varies from one society to another and needs to be practiced in strict adherence to those attributes, which define it in its western conception. Democracy, in most parts of Africa, and Cameroon in particular, is still in its infancy and in very poor, and sometimes ethnically divided, conditions.

As Achia rightly put it, in Cameroon for instance, democracy is a sham; it is like a veil on the bride's face that prevents people from discerning the true appearance of the bride - an autocratic system of government in disguise of democracy (Alexander, 2009). Similar to Cameroon is the Democratic Republic of Congo for instance, where democracy exists only in name.

This is so because, since the forty years of independence, Congo has seen around thirty-two documents dubbed Constitution, revising a constitution almost every fifteen months (Manga, 2002). A clear understanding of the concept of democracy shows that the identity of a state does not depend on its fiscal characteristics or on the number of times a constitution has been altered; it rest on the democratic values that underpin the constitution.

Such are the characteristics of a truly democratic society. Despite several constitutional changes, the trend of democratisation taking shape in many African states and Cameroon, in particular, has paradoxically not yet produced the expected result of society and constitutional transformation; cases of poverty, corruption, insecurity resulting from lack of accountability, terrorism, civil war, among others, still define the trajectory of many African states.

This has impeded complete transformation in constitutionalism, democracy, and questions the effective protection and enjoyment of fundamental human rights in Cameroon.

\subsection{The Rule of Law}

The success of every democracy relies on the existence, respect for, and upholding of the rule of law. Rule of law implies respect for human rights, protection of personal freedoms, equality before law, accountability to the law, and the absence of an arbitrary government (Abraham, 2013).

Rule of law is often perceived as a guiding principle that the court depends upon; a doctrine that inspires every constitution. From the perspective of international human rights, rule of law requires domestic legal orders of the contracting states to effectively implement the international guarantees. Undoubtedly, constitutionalism is safeguarded by the rule of law, and without the rule of law, there can be no constitutionalism.

According to the UNDP, the rule of law rests at the centre of the relationship between society and the state. Measures to establish or strengthen the rule of law are the basis for creating accountability among people as well as between citizens and their governments (United Nations Development Programme, 2016). It creates the foundation for sustainable peace and the imperative for peace, security, development, and human rights. ${ }^{19}$

In Klass and Others v Germany, the European Court of Human Rights (hereinafter ECtHR) observed that 'one of the fundamental principles of a democratic society is the rule of law.' 20

It implies, inter alia, that interference by executive authorities on an individual's rights should be subject to an effective control, which should normally be assured by the judiciary, at least as a last resort. ${ }^{21}$ The rule of law is based on the principle that law should govern a state, as opposed to being governed by the decisions of individual government officials. It also demands that law should hold authority within a society with some degree of certainty. However, if laws are secret or imprecise, retrospective, contradictory, impossible to access, understand, or perform, they do not add up to the rule of law (Krygier, 2012).

\footnotetext{
17 Art. 8 of the Vienna Declaration and Programme of Action adopted by the World Conference on Human Rights in Vienna on 25 June 1993 ; See also principle V of the UN Millennium Declaration Adopted 8 September 2000; Principle 14 World Summit Outcome of 16 September 2005.

${ }_{18}$ President Barack Obama (Former US President) to the Ghanian Parliament at Accra International Conference Center, Accra, Ghana, 11 July 2009 $<$ https//www.whitehouse.gov/the-press-Office/remarks-president-ghanaian-parliament $>$ accessed 11 September 2017

${ }^{19}$ Ibid, 1.

${ }^{20}$ Klass v Germany (1978), Application No.5029/71, para. 55.

${ }^{21}$ Ibid, para. 55.
} 
According to Cass Sustein, rule of law requires restrictions to be clear rather than vague and publicly available, rather than secret; it must operate in the world as it does in the books (Sustein, 1992). In Cameroon, unlike in other post-colonial African states such as South Africa, the domestic laws are contradictory, opaque, and unintelligible.

These laws are obeyed by the government and to them, the state is governed based on the rule of law. This often provokes many constitutional law scholars to question if the rule of law really exists in Cameroon. The concept of the rule of law, while not entirely uncontested, entails at least a legal certainty and clarity, and it is aimed at protecting basic individual rights by requiring the government to act in accordance with the law. A close examination of Cameroon's constitution will assert this point of contention: though the constitution contains democratic values, most of its clauses or provisions are at odds with the Penal Code ${ }^{22}$ and lack specificity, leaving authorities with the utmost discretion to determine clarity in any given case. Refer to, for example, the principle of legality (nullum crimen, nulla poena sine lege), which states that the law may not have retrospective effect. No person may be judged and punished, except by virtue of a law enacted and published before the offense committed'. ${ }^{23}$

Similarly, the preamble to the Constitution states that 'the freedom of communication, of expression, of the press shall be guaranteed under the conditions fixed by law.'

The use of the words 'may' and 'under the conditions fixed by law' are conditional expressions, leaving the courts or those in power with a broad discretion to determine whether a given offense committed is contrary to the law or when freedom of expression can be subjected to restrictions.

Moreover, it will be difficult, if not impossible, for any affected citizen to know ex-ante the exact rules that may apply to their cases. A.V Dicey has made some interesting points on the discretionary powers, listing out three important characteristics upon which the rule of law depends:

'Firstly, that the rule of law depends on the system of government which excludes "the exercise by persons in authority of wide, arbitrary or discretionary powers of constraint". The second is the universal subjection to "the ordinary law of the realm and amenable to the jurisdiction of the ordinary tribunals and lastly, a system whereby the 'general principles of the Constitution" are developed as the result of judicial decisions determining the rights of private persons in particular cases brought before the courts; whereas under many foreign constitutions the security(such as it is) given to the rights of individuals results, or appears to result, from the general principles of the Constitution (Dicey, 1959).

As much as I disagree with Dicey's point of contention on wide or discretionary powers of constraint, somewhat because of its remoteness, going his way enables flexibility in many circumstances of governance, giving room for judicial activism. On the other hand, I concur with the fact that it brings about distortion and excessive violation of constitutional rights.

This implies that discretionary or wide powers, accorded by the constitution or law, are incompatible with the rule of law. This is so because holders or authorities will typically construe them for their own selfish interests against the concern of the majority.

This argument speaks for itself - mutatis mutandis - in a parliamentary system of government based on authoritarianism, as is the case in Cameroon, Zimbabwe, Equatorial Guinea and the Democratic Republic of Congo. Such a system or government will take little or no efforts to ensure accountability and hinder constitutionalism and transformative constitutionalism.

\subsection{Human Rights Protection}

The pressure from the international community for universal human freedom and life with dignity, coupled with promises of improved bilateral relations for non-dictatorial states stimulated the internal drive for democratisation of African nations. Prior to the end of World War II, constitutional law was mainly focused on governmental rules, democratic constitutions, and on the framework of electoral politics, while rights were deemed not justifiable.

Among the most basic functions of the constitution is to guarantee fundamental human rights and institutions or mechanisms to ensure their effective protection and enforcement. These rights are imperative for the legitimacy or moral respectability of democratic decision-making in every member state of the African Charter on Human Rights. ${ }^{24}$ As noted in Article 16 of the French Declaration on the rights of man, any society in which the guarantee of rights is not assured has no constitution. ${ }^{25}$

\footnotetext{
22 See Section 1 of the Penal Code, which states that 'all men without distinction are equal before the law', contrary to the preambular clause in the constitution, which ensures the well-being of every citizen without discrimination. See also section 347 , which sanctions homosexuality contrary to the right to privacy entrenched in the Constitution etc.

${ }^{2 s}$ Preamble to the Cameroon Constitution, 1996; Section 17 of the Revised Penal Code 2016.

${ }^{24}$ African Charter on Human and People's Rights, adopted 27 June 1981, entered into force 21 October 1986, OAU Doc. CAB/LEG/67/3rev.5, 21 I.L.M. 58 (1982).

${ }^{25}$ French Declaration on the Rights of Man, adopted 26 August 1789.
} 
According to Mamdani, 'the discourse on human rights and constitutionalism in contemporary Africa remains a contested terrain and should not be seen as a settled issue.' ${ }^{26}$ As much as I may agree with him, it is important for us to note that the 'terrain' is not less contested in Africa compared to other parts of the world. This controversy lies in the fact that the debate over constitutionalism and democracy has been turned into an ideology.

Undoubtedly, all constitutional rights are rights; however, not all rights are constitutional. According to Robert Alexy, constitutional rights are rights that have been recorded in a constitution with the intention of transforming human rights into positive law (Alexy, 2012).

Although the 1996 Constitution ensures fundamental human rights to citizens in Cameroon, these rights are merely embedded in the preamble, not in specific texts but in clawback clauses with no specificity, which leaves judges with the utmost discretion to determine the scope of protection and any possible violation.

This illustrates how easily human rights are or may be violated owing to the existence of laws that are not precise enough; thus, the laws are vulnerable to false interpretation by local administrative and political authorities for their own benefits and against the interests of precisely those whom the laws were meant to protect.

Although judges are the best decision-makers on questions of rights, any democratic gain that results from giving judges the power to interpret rights associated with democracy must be set off against procedural cost. This, in turn, allows greater possibility of malfunction with regard to accountability resulting from a non-respect or violation of individual's rights.

The powers accorded to legislative authorities for legal interpretation of rights by the constitution may pose a problem of enforcement. One answer to this problem of disagreement lies in the interpretative resources available to judges.

Such resources include the text and structure of the bill of rights within the constitution, the original intention of the framers or the original meaning of the relevant provisions, and any relevant judicial decisions. The argument would be that, where judges rely on these resources, they do not make an unconstrained 'moral' judgment on the meaning of an abstract concept like 'equality' or 'freedom of speech' but a constrained 'legal' judgment.

However, I do not hold this as a very promising line of argument to ensure effective protection of rights in the Constitution. The 1972, 1984, 1996, and 2008 constitutional amendments in Cameroon were perceived as a new wind of change or transformation that would ensure effective protection and accountability of human rights, freedom, equity, rule of law, and liberty, but they remain far from the original objective.

The lack of specific texts or provisions that define specific rights, their scope, limitations, and the interpretative approach in the 1996 Constitution has prompted one to encourage interpreters of the constitutional text to share an understanding of the meaning of the text found in the extrinsic evidence of original intent or meaning.

Even though Article 45 of Cameroon's constitution may be used to enforce the interpretative approach to human rights protection, it is, however, less informative. ${ }^{27}$ On a contrary, a closer look at the fundamental human rights entrenched in the South African Constitution or Bill of Rights as compared to Cameroon shield democratic processes by preventing democratic 'malfunctions' that entrench the powerful or disregard minorities. ${ }^{28}$

According to Article 39 of the South African Constitution, when interpreting the Bill of Rights, the courts must 'promote the values that underlie an open and democratic society based on human dignity, equality, and freedom.' ${ }^{29}$ This provision appears to be informative and has expanded the interpretative approach towards these rights, given that it gives the court wide latitude in the determination of such matters.

A critical examination of the Constitution of Cameroon in practice will demonstrate that the protection of human rights is only partially enforced by the courts, but they receive full enforcement through the executive arm of the government.

This shows that the constitution is political, and as such, it obstructs complete transformation. Even with the increasing notion of constitutionalising international human rights law and internationalisation of constitutional law around the globe, the idea of constitutional incorporation of human rights into domestic constitutions is still a deadlock in many African states. Apparently, a great number of states, including Cameroon, have ratified both the Covenant on Civil and Political Rights ${ }^{30}$ and the Covenant on Economic, Social and Cultural Rights ${ }^{31}$, and the list of constitutional rights in most constitutions such as South Africa and Kenya presents a strong resemblance with the two Covenants. Yet, what is written is not always reflective of what is occurring in practice. According to Wen-Chen and Jiuun-Rong, the ratification of human rights

${ }^{26}$ Mamdani M, 'Social Movements' (n 16) 98

${ }_{27}$ Art. 45 states that duly approved or ratified treaties and international agreements shall, following their publication, override national laws, provided the other party implements the said treaty or agreement.

${ }^{28}$ See Chapter 2 of the Constitution of the Republic of South Africa, 1996

${ }^{29}$ See also section 2(5) of the Revised Constitution of Kenya, 2010.

${ }^{30}$ International Covenant on Civil and Political Rights, adopted 16 December 1966, entered into force 23 March 1976: 999 U.N.T.S. 171; Ratified by Cameroon on 27 June 1984.

${ }^{31}$ International Covenant on Economic, Social and Cultural Rights, adopted 16 December 1966, entered into force 3 January 1946: 993 U.N.T.S. 3; Ratified by Cameroon on 27 June 1984. 
treaties has not yet imposed a direct obligation on states for domestic constitutional or legal incorporation, let alone direct judicial enforcement (Wen-Cheng \& Jiunn-Rong, 2012).

This dilemma has also hindered constitutionalism and TC agenda in most post-colonial African states and Cameroon in particular. This has prompted many constitutional law scholars to describe constitutional changes in post-colonial Africa's history as 'Constitutions without constitutionalism' (Prempeh, 2007).

There is, therefore, an urgent need to provide specific limitations to those rights contained in the constitution that are subject to derogation. Through this, ambiguity and misinterpretation of constitutional provisions by ordinary citizens would be avoided.

\section{The 1996 Constitution and its Transformative Agenda}

The Constitution of Cameroon, subject to several changes or amendments, appears to have laid down a transformative agenda towards constitutionalism and TC. This can be affirmed following the guarantee of the principle of separation of powers, judicial independence, and review of the constitutionality of laws. How this functions in practice appears to be the opposite of what is on paper.

The effectiveness or efficiency of every democratic society will depend on how these organs function and respect the limit imposed by the constitution. A careful assessment of the principles of separation of powers, checks and balances, and review of the constitutionality of laws under the 1996 Constitution compared to the South African postamble will attest to whether the Cameroon Constitution offers an example of TC in postcolonial Africa.

\subsection{Separation of Powers and Independent Judiciary}

Separation of powers is a very significant factor for enhancing constitutionalism. As noted by the French Declaration of the Rights of Man, any society in which the separation of powers is not observed has no constitution. ${ }^{32}$

The principle of separation of powers, in its simplest and probably most extreme form, basically requires the three branches of government - the executive, legislative, and judicial branch - should be kept separate from each other. In Cameroon, unlike in most post-colonial African states, the doctrine of separation of powers appears to be mixed.

The Constitution of Cameroon seems to have adopted the rigid French system of separation of powers. Accordingly, the Constitution provides that, justice shall be administered in the territory of the Republic in the "name of the people of Cameroon" and judicial power shall be independent of the executive and legislative powers ...'s3 The question raised is whether there is indeed judicial independence and separation of powers in actual practice in Cameroon.

An answer to this question is reminiscent of Montesquieu's theory of separation of powers. The idea of separation of powers was first put in place in 1748 by Montesquieu in his book titled De L'esprit des loi (The Spirit of Laws). ${ }^{34}$

He propounds that, for there to be efficiency and accountability in governance, the political power of the legislature, the executive, and the judiciary must be separated and be independent of each other. Unlike in Cameroon, where there is no express entrenchment of separation of powers, in the South African constitution, the Constitutional Court in the case of South African Personal Injury Lawers $v$ Health notes that 'there can be no doubt that our constitution provides for such separation of powers.' ${ }^{35}$ Recognised as the most important, the independence of the judiciary has to be real and not apparently mere and unchecked.

This approach was to present and defend a form of government that was not excessively centralised in all its powers to a single monarch or a similar ruler. An independent judiciary can be defined as one that is free to render justice on all issues of substantial legal and constitutional importance, fairly, impartially, and in accordance with the law without threat, fear of reprisal, intimidation, or any other undue influence or consideration. ${ }^{36}$ As Mark put it, in a well-designed separation-of-powers system, the members of different branches are selected by different processes; for that reason, they are likely to seek to implement different policies. ${ }^{37}$ In Cameroon, for instance, the separation of powers in the 1996 Constitution is purely symbolic. ${ }^{38}$ This is principally due to the lack of good will to allow the judiciary to operate independently and effectively without political interference.

\footnotetext{
32 Art.16 French Declaration of the Rights of Man and the Citizen, adopted 26 August 1789; See also Art. 26 of the African Charter on Human and Peoples Rights and Art. 14(1) ICCPR 1966.

${ }^{33}$ S.37(1)(2) of the Cameroon's Constitution, 1996.

${ }^{34}$ Montesquieu, De L'esprit des loi (1748)

${ }^{35}$ South African Personal Injury Lawyers v Health 2001(1) SA 883(CC), para.18.

${ }^{36}$ Charles Manga F, (n 21) 15 .

${ }^{37}$ Mark Tushnet (n 15) 227.

${ }^{88}$ Charles Manga F(n 14) 1017.
} 
Even though Article 37(2) of the Constitution provides for an independent judiciary, the extent of this independence is defined or determined by the executive. ${ }^{39}$ As a guarantor of the separation of powers, the President is above the law; otherwise, there can be no judicial independence. Judicial independence has a correlation with the supremacy of the law, and everybody is equal before the law. The courts should not exceed their proper role, regardless of whether they would enhance legislative or executive power.

The vague language in Section 37(3) of the Constitution leaves the implementation of this provision entirely to the discretion of the president of the republic. Although the Penal Code sanctions the violation of the principle of separation of powers, this has, however, not been put into practice. ${ }^{40}$

The dominance of the President has been strengthened, with extensive unilateral powers, enabling him to appoint and dismiss members of the bench, legal department, the Prime Minister, and other members of the government at his pleasure. ${ }^{41}$ Apart from being the guarantor of the independence of the judiciary in the state, the President can also approve or veto newly enacted laws, authorise public expenditures, and declare a state of siege and emergency in the event of a serious threat to the nation's territorial integrity. ${ }^{42}$

In the case Secretary of state for the Home Department $v$ Rehman, the ECtHR Special Immigration Appeals Commission (SIAC) had rejected the government's argument that the question of what could constitute a threat to national security was a matter of exclusive decision of the Secretary of State. ${ }^{43}$

Although it is within the limit of the executive branch to decide on what is in the interest of national security during a state of emergency, such decisions must be based on precise conditions and procedures laid down by law.

According to the Constitution, the head of state is regarded as a symbol of national unity, who is required to define the policy of the nation, ensure the respect of the constitution, the proper functioning of public authorities, the guarantor of the independence of the nation and its territorial integrity, of the permanency and continuity of the state, and the respect of international treaties and agreements. ${ }^{44}$

The constitution confers broad and absolute powers to the head of state, who also happens to be the military commander.

Unlike Section 37 of the South African Constitution and Section 58 of the Kenyan Constitution, ${ }^{45}$ the conditions or procedures creating or leading to the state of emergency have never been specified in advance by Cameroon's constitution. According to Schmitt, in liberal constitutions, the only political actor well positioned to declare a state of exception is the executive.

He appears to have assumed that the executive would always have strong incentives to declare emergency when they find their major initiatives frustrated by political opposition (Carl, 2007). To the best of my knowledge, this emergency powers limit or is at conflict with constitutionalism and is a very big challenge to the modern and liberal constitutionalism that every democratic state seeks to protect.

Although the interdependent role among the various arms of government is also a necessary means to ensure dialogue or negotiation when it comes to matters relating to budget, jurisdiction, size, procedures, and administration. However, it does not require the domination of one over another.

The purpose of separating functions is to prevent excessive concentration of powers in the hands of one branch (Wellman, 2016). Some commentators have argued that separation of powers promotes greater governmental efficiency and accountability (Currie \& De, 2005).

The African Commission, in its recent decision in Gumne et al v Cameroon, expressed discontent and affirmed that the Cameroonian judiciary is independent. ${ }^{46}$ The Commission, however, argues that the doctrine of separation of powers requires the three pillars of the state to exercise powers independently and that the executive branch must be regarded as separate from the judiciary and the legislature.

Likewise, in order to guarantee its independence, the judiciary, must be regarded as independent of the executive and parliament. ${ }^{47}$

A critical observation of Section 37(3) of the Constitution of Cameroon affirms that the judiciary in Cameroon is not an independent institution. ${ }^{48}$

\footnotetext{
${ }^{39}$ Art 37(3) states that the President or head of state shall guarantee the independence of the judicial power and shall appoint members of the bench and of the legal department. He shall be assisted in this task by the Higher Judicial Council (HJC), which shall give him its opinion on all nominations for the bench and on disciplinary action against judicial and legal officers. The organization and functioning of the Higher Judicial Council shall be defined by law: ${ }^{40}$ Ss. 126 and 127 of Law No 2016/007 of 12 July2016 Relating to the Penal Code.

${ }^{41}$ See section 10 of Cameroon's Constitution 1996.

${ }^{42}$ SS. 8, 9,31 and 36; See also S1-3 of Law No.90/47 of 19 December 1990 relating to the state of Emergency in Cameroon; See also art. 16 of the French Constitution of 1958, which grants broad emergency powers to the executive without conditions for declaration

${ }^{43}$ Secretary of State for the Home Department v Rehman (2002) 1 All ER 123

${ }^{4}$ S. 5 Constitution 1996

${ }^{45}$ Revised Constitution of Kenya, 2010.

${ }^{46}$ Communication No.266/2003 ACHPR (05/2009), paras. 209-212.

47 Ibid, paras, 211-212.

${ }^{48}$ Art. 37 of the Constitution state that the President of the Republic shall guarantee the independence of the judicial power. He shall appoint members of the bench and of the legal department and shall be assisted in his task by the Higher Judicial Council, which shall give him its opinion on all nominations for the bench and on disciplinary actions against judicial and legal officials.
} 
As such, a judiciary that is not independent from the executive may not be impartial towards parties, if one of them is the government. In the locus classicus of Campbell and Fell $v$ United Kingdom, the ECtHR opines that the requirement of independence entails safeguards relating to 'the manner of appointment of judges, the duration of their office, the existence of guarantees against outside pressures, and the question whether the body presents an appearance of independence.' 49

Although the 1996 Constitution provides for the separation of powers amongst the various arms of the government, this is largely ineffective because of the President's unrestricted power to appoint and dismiss judges. It is indisputable that, in most parliamentary systems, the executive is delegated the power to appoint judges, magistrates, and ministers, and not by ballot.

It is obvious that, in a despotic system of government such as Cameroon's, the attainment of justice will become autocratic.

Whenever there is a conflict between an individual and the government, it is likely that the court or judges would rule in favour of the state for fear of dismissal, even when the state is wrong or at fault. Therefore, the lack of a practical separation of powers and effective judicial independence evidences that the 1996 Constitution is yet to attain its transformative agenda.

This has also been one of the setbacks for constitutionalism or constitutional development in Cameroon and the enforcement of justice.

\subsection{Checks and Balances}

The principle of checks and balances is a system-based regulation or rule that allows one branch of the government to limit the other. In other words, it seeks to prevent one branch from becoming supreme and induces the various branches of government to collaborate with one another. For instance, in Cameroon, the situation is a nightmare.

Even though Section 37(2) of the Constitution ensures separation of powers, so far, this has not been put into practice, as independence is guaranteed to the judiciary by the Head of State. ${ }^{50}$

The excessive concentration of powers in the hands of the President through constitutional amendments has subjected the other branches of the government to full control. This appears to have hindered accountability in any act implemented by the executive branch, most especially when it concerns human rights violations and issues related to corruption.

An inadequately conceived system of separation of powers with insufficient checks and balances creates a condition of imbalance, which can provide scope for a more powerful arm to usurp power and rule by authoritarianism. $^{51}$

The absence of a practical constitutional text authorising checks and balances among state authorities has rendered constitutionalism and TC a dream of the western world above the African culture. A failure to incorporate credible checks and balances into Africa's post-authoritarian constitutions have allowed the burden of promoting and sustaining constitutionalism to fall disproportionately on the third branch of government, the judiciary, rather than on structural reforms of state and government. This leaves the executive branch with broad and direct influence to intervene and manipulate in any decision-making process to fulfil self-serving interests.

This has created doubt as to whether the bill of rights and judicial review mechanisms can alone secure and sustain constitutionalism in contemporary Africa and Cameroon in particular.

\subsection{The Review of Constitutionality of Laws and Constitutional Amendments}

The strength of every democratic society is dependent upon the extent to which national laws are consistent with constitutional amendments.

Constitutional review demands that laws adopted by the parliament or the executive branch, which contravene the constitution, should be reviewed and reversed as far as they violate any of the provisions of the Constitution.

As noted by H. Kwasi, judicial review does not only mean that the court may strike down a legislative action as unconstitutional, but also that it may validate it as within constitutionally granted powers and as not violating constitutional limitations (Prempeh, 2007).

This may be so because the constitution is considered the supreme law of a state and other existing laws derive their validity from the constitution. ${ }^{52}$ This function is most often carried out by a court or a special body designated to supervise the constitutionality of laws.

\footnotetext{
${ }^{49}$ Campbell and Fell v United Kingdom, Application No 7819/77 (1984), para.78.

${ }^{50}$ See Section 37(3) of the Constitution, 1996.

${ }_{51}^{51}$ Laura-Stella Eposi E, (n 23) 103.

${ }^{52}$ See art. 2 of the South African Constitution, 1996.
} 
As Charles strongly argued, the important bulwark of constitutionalism is, therefore, the existence of an efficient and effective mechanism for controlling and compelling compliance with the constitution (Fombad, 2007). Arguably, the long absence of a tradition of parliamentary autonomy in post-colonial Africa has severely impaired Africa's legislatures in defining or protecting their institutional interests and prerogatives (Prempeh, 2007).

In a parliamentary system, such as Cameroon's, the constitution designates a special body to exercise powers or to supervise the constitutionality of laws.

According to Section 46 of the Constitution, the Constitutional Council shall have jurisdiction in matters pertaining to the Constitution (...) and shall rule on the constitutionality of laws. ${ }^{53}$

Unlike in Cameroon, where the Constitutional Council is designated as the primary body responsible for ruling on the constitutionality of laws, the Constitutional Court in South Africa and the Federal Constitutional Court in Germany seem to be responsible for that function. ${ }^{54}$

This implies that the Constitutional Council, now Supreme Court, ${ }^{55}$ has the right to rescind any law or act of the government violating a constitutional norm, the power to refuse any amendment, or violating the rule of law or protected constitutional rights.

It also implies the supremacy of the Constitution. In spite of this promise, the Supreme Court remained silent and failed to uphold the unconstitutionality of the 2008 amendment, which eliminated and extended the presidential term limit of five to six years in the Constitution, leading to an extensive violation of the rule of law, fundamental human rights, most especially of free expression, fair trial, and the right to life. ${ }^{56}$

For instance, late Pierre Roger Lambo Sandjo(alias Lapiro de Mbanga), a Cameroonian singer and an outspoken critic of the government, was sentenced to three years' imprisonment for singing against the constitutional amendment in a song titled 'Constipated Constitution (Anna, 2009).

This can be attributed to the fact that the Constitutional Council or the Supreme Court is a paperwork institution paying loyalty to the President rather than repealing any unconstitutionality through an amendment initiated by the President or where his interests will be at stake.

As such, they prefer to favour the President rather than protect the constitution, its supremacy, the rule of law, and fundamental human rights guaranteed by the constitution. As rightly said, in the absence of any limits or restrictions on the amendment of a constitution, it is extremely difficult to promote constitutionalism, respect the rule of law, democracy and good governance (Fombad, 2007).

The Supreme Court, which is presently playing the role of the Constitutional Council since 1996, has been given the absolute task to declare all legislative acts contrary to the constitution null and void. Coupled with its lack of independence, they hardly rule on the unconstitutionality of laws even when a law or an act contravenes the constitution. For example, the Anti-Terrorism Law ${ }^{57}$, which incorporates death penalty as a sanction contrary to the right to life embedded in the constitution, was adopted by the Head of State without the Supreme Court ruling on its constitutionality status.

Their silence was meant not only to fight terrorism, no matter in which direction the law may have been intended, but also to protect the incumbent regime from any popular uprising. So far, this has fortified the rights of the government and not its citizens.

A system of review of constitutionality that makes the control predominantly dependent on the judiciary or the executive branch is clearly a sham, diminishing all prospects for constitutionalism. This was the case under the Angolan, Madagascan, and Mozambican constitutions. ${ }^{58}$

The mere granting of judicial review power, even under conditions of judicial independence, offers no assurance that it would be employed for the cause of constitutionalism (Prempeh, 2007). From the history of constitutional amendments in Cameroon since its independence and following the creation of the 1996 Constitution, one can unequivocally assert that the concept of constitution and constitutionalism remains a fallacy or a deadlock in Cameroon.

This is because the process of constitutional reviews has hindered constitutional efficacy and transformation in Cameroon.

\section{Challenges}

The challenges towards transformative constitutionalism in Cameroon and post-colonial Africa, in general are daunting. The post-war paradigm, including the introduction of multi-party politics, in Africa was seen by many as an end to authoritarianism, a new drive to democracy, and equal access to justice for all. This was envisaged through the establishment of national constitutions and amendments that ensured peace, stability, and cooperation among states. However, short of appreciation, the desire for superiority and economic

\footnotetext{
${ }^{53}$ See arts. 46, 47(2)(3), and 48(3) of the Constitution; Law No.2004/004 of 21 April 2004 on the organization of the Constitutional Council. ${ }_{54}$ See Sections 80 and 74 of the 1996 South African Constitution and Sections 93(2) and 100 of the German Basic Law (Verfassung)of 1949.

55 It should be emphasised here that, since 21 years after the allocation of power to this body, the Constitutional Council is still to be instituted, and its functions, under article 47 of the constitution, are presently exercised by the Supreme Court with the same restrictions with respect to those who can take issues dealing with the constitutionality of laws before it, unlike ordinary citizens.

${ }_{56}^{56}$ See art. 6(2) of the Constitution.

${ }^{57}$ Law No.2014/028 of 23 December 2014 on the Suppression of Act of Terrorism.

${ }_{58}$ Charles Managa F (n 21) 20.
} 
interests (in mineral resources) by former colonial powers has hindered the achievement of a long-lasting peace for constitutional developments and transformation in Africa.

One of the greatest challenges towards TC in some African states has been the persistence of civil war and insecurity resulting from terrorism, legal cultures and traditions, legal education, corruption, the quest for power or reluctance to relinquish power, and the lack of political willingness. These factors seem to have impeded the development of constitutionalism.

In Cameroon similar to elsewhere in the world, for instance, Kenya and South Africa, legal culture plays a significant role for transformation. Legal cultures and traditions impact the way democratic values and systems are built and supported. According to Karl Klare,

TC is the perfect architect for entrenching a legal culture safeguarding the principles of constitutional democracy (Klare, 1998).

However, the significance of legal culture in constitutional transformation is to be considered. In general, legal culture concerns the broader perspective of how the constitution is interpreted, how the law is applied and practiced, and how it influences legal developments in the country.

It concerns the nature of characteristic, legal values, expressions, and arguments by legal practitioners and those in other disciplines. Apparently, the Cameroonian legal culture is conservative, posing a structural impediment towards a comprehensive realisation of TC ideals, and thus, it requires a modern approach.

As such, courts should not be constrained in the interpretation and application of the law in the constitution; the essence being that TC envisages achieving legal and social change in broader terms, which can only be achieved where courts consider circumstances in each case to give effect to the transformative ideals. Hence, the adjudication process ought to explicitly adapt an activist transformative approach.

Moreover, owing to the overconcentration of power in the hands of the executive branch and a firm grip on power, most African political leaders or states are dictatorial in nature and resistant towards initiating a change by relinquishing power when their term in office conclude.

The fear of persecution as a result of their ill practices during their term in office has prompted most leaders to effect negative changes in constitutions, extending their terms of office so they extensively and indefinitely remain in power. This demonstrates a lack of political will to effect a positive change or embrace transformation. Their desire to become presidents for life has also prompted them to institute oppressive laws for protecting their selfish interests and positions.

A clear illustration can be seen in Cameroon, Democratic Republic of Congo, Zimbabwe, Togo, and Equatorial Guinea. As such, the continuous application of repressive, draconian laws, for instance defamation laws and laws on contempt of president, from ancient regimes remain good in Cameroon and continue to be enforced. ${ }^{59}$

The application of these laws by public officials in the post-transition period has, to some extent, resulted in constitutional challenges in Cameroon and the rest of Africa. This has hindered the TC agenda at the expense of individual interests, and consequently, it is a failure to effect a positive change as previewed by the constitution.

\subsection{The Cameroonian Constitution and Proposals for Reform}

Though many would argue or agree that constitutional transformation and the entrenchment of fundamental rights in the constitution does not necessarily entail effective enjoyment and enforcement, I strongly believe that a complete transformation along with entrenchment of fundamental rights in the constitution in specific provisions or texts, the establishment of effective mechanisms, and a complete separation of powers and checks and balances will open a new chapter in the Cameroonian Constitution, which could not only ensure fundamental rights but would enhance democracy, the rule of law and equal participation of people in the democratic process.

A careful observation of the South African postamble, which contains a specific Bill of Rights, would affirm that fundamental human rights and accountability have been ensured. Nevertheless, it is still plagued with the problem of effective enforcement of the rights it ensures, such as racial inequality, low standards of socio-economic empowerment, and poor access to adequate medical/healthcare services, and other basic facilities (Endoh, 2015).

The entrenchment of rights with some degree of certainty at least provides the people or nationals the hope of effective protection and enforcement rather than the opposite.

This is the bulwark of a democratic society and the rule of law and a replica of TC, which post-colonial Africa has longed for since the aftermath of World War II and the independence movements. One of the failures of the 1996 Constitution has been the non-activating or establishment of the Constitutional Council that ensures the constitutionality of laws contemplated in Cameroon.

Though this function is being carried out by the Supreme Court, short of appraisal, one will say the court is plagued by corruption, lacks the absolute independence to effect positive change, adequate resources

${ }^{59}$ See Sections 153,154 of Law No2016/007 of 12 July 2016 relating to the Penal Code. 
(Bertelsmann, 2016) and is burdened with a backlog of cases that require more time in adjudication rather than ruling on the constitutionality of laws.

A critical observation of the composition and the process of employment will affirm that the judges elected by the head of state are predominantly of the ruling party and will favour any legislation put in place in so far as it protects the interests of their 'Godfather'.

In such a matter, the lack of neutrality and independence of judges do not only demand an urgent constitutional review or reform; it requires a complete transformation that enhances the constitutionality of the laws, which will conform with constitutional and democratic values. A significant change that requires critical analysis shows that there is still room for important contributions.

Other states on other continents, especially North America and Europe, went through the struggle for constitutionalism and democracy: struggle for freedom or independence, wars, conflicts, rebellions, agreements to end wars and conflicts, transition, establishment, and consolidation of democracy. It is, therefore, no shame for Africa to learn from others' experiences to address internal crisis or conflicts.

Some states in Africa should also learn from other states in the continent in a positive way, just as Cameroon should learn from South Africa to enhance constitutionalism and TC and to recede from authoritarianism and conflicts.

\section{Conclusions}

Many important changes have undoubtedly taken place in constitutional politics in post-colonial Africa since the aftermath of colonialism and the introduction of multi-party politics. However, these changes made in the early 1990s must be regarded as incomplete, and as such, there is an inevitable need for additional reforms, one that will shift the emphasis from merely installing electoral democracies to building firmer structural and institutional foundations for constitutionalism.

TC remains one of the most viable and potent options for change in Africa and Cameroon, in particular, which is capable of ensuring protection of all citizens.

A desire for a new constitutional transformation, which will ensure democracy, the rule of law, the accountability of states authorities, equal participation in the democratic process, and the effective protection and guarantee of fundamental human rights and freedoms, is highly required in Cameroon; otherwise the country will slide into a conflict or instability that would stem from hatred among its citizens caused by wide omissions in the present constitution.

The recent anglophone crisis, which emerged since October 2016 until today, is just a signal of what might happen in the near future if the state does not think towards this direction.

The attempts by the government to introduce limited democratic reforms have fallen far short of expectations up till now, as exemplified by the widespread abuse of human rights and the most blatant forms of corruption reported in high office, such as administrative departments.

As Alexander rightly said, the separation of powers is an instrument that discourages corruption (Alexandere, 1999).

The lack of practical separation of powers in the constitution has rendered corruption inevitable in the Cameroonian system; thereby, it has granted more voice to the rich than the poor. This has exposed the degree of the ineffectiveness of constitutional mechanisms in bringing about transformation.

Although globalisation in democracy and human rights has come along with challenges, one cannot ignore participatory democracy and human rights without securing transformation in constitutional systems or processes, since democracy and $\mathrm{TC}$ is a civilized value for fostering a principle that would build a new world order. African states, in general, and Cameroon, in particular, must make diligent effort to unveil the shroud of ignorance on the politics behind constitutionalism and TC. Along this line of thought, the state would build a better society and future, enhancing democracy, the rule of law and human rights for everyone within its territory.

\section{References}

Abraham, L. (2013). Towards an African theory of democracy: Thoughts and practices' (n 41) 121; Christian Tomuschat, 'Democracy and the Rule of Law' In Dinah Shelton (ed) The Oxford Handbook of International Human Rights Law (1st ed., pp. 489): Oxford University Press

Alexander, A. (2009). World youth movement for democracy, essay contest African regional winnerCameroon (World Youth Movement for Democracy). Retrieved from http://www.wymdonline.org/docs/AfricaFoto.pdf.

Alexandere, H. (1999). The Federalist Constitutionalism: Clinton Rossiter.

Alexy, R. (2012). Rights and liberties as concepts in Michel Rosenfeld and Andras Sajo (eds), The Oxford Handbook of Comparative Constitutional Law (1st ed.): Oxford University Press.

Anna, M. (2009). Constitutional protection in Cameroon: A critique of the amendment mechanism. Central European University. 
Bertelsmann, S.-B. (2016). Cameroon country Report (Gütersloh: Bertelsman Stiftung) 9-10. Retrieved from: https//www.bti-project.org/fileadmin/files/BTI/Downloads/Reports/2016/pdf/BTI_2016 _Cameroon.pdf.

Carl, S. (2007). The concept of the political George Schwab Trans and ed.

Currie, I., \& De, W. J. (2005). The bill of rights handbook (5th ed.). Juta.

Dicey, A. V. (1959). Introduction to the study of the law of the constitution (10th ed., Vol. 188).

Dieter, G. (2012). Types of constitutions. In Michel Rosenfeld and Andras Sajo (Eds.), The Oxford Handbook of Comparative Constitutional Law (1st ed., pp. 116-124): Oxford University Press.

Endoh, F. T. (2015). Democratic constitutionalism in post-apartheid South Africa: The interim constitution revisited. Africa Review, 7(1), 67.

Fayemi, A. K. (2009). Towards an African theory of democracy: Thought and practice. Journal of the Philosophical Association of Kenya, 1(1), 101.

Fombad, C. M. (1998). The new Cameroonian council in a comparative perspective: Progress or retrogression. Journal of African Law, 42(2), 172.

Fombad, C. M. (2007). Challenges to constitutionalism and constitutional rights in Africa and the enabling role of political parties: Lessons and perspectives from Southern Africa. American Journal of Comparative Law, 55(1).

Fombad, C. M. (2011). Constitutional reforms and constitutionalism in Africa: Reflections on some current challenges and future prospects. Bufalo Law Review 1007, 59(4).

Francis, D. (2008). Identity, diversity and constitutionalism in Africa (USIP 2008).

Gardbaum, S. (2012). The place of constitutional law in the legal system in Michel Rosenfeld and Andras Sajo (Eds), The Oxford Hand Book of Comparative Constitutional Law (1st ed., pp. 169-185): Oxford University Press.

Garner, B. A. (2001). Black's law dictionary (2nd ed.): West Group Publisher.

Githiru, F. M. (2012). Transformative constitutionalism, legal culture and the judiciary under the 2010 constitution of Kenya (Pretoria University) Retrieved from https://repository.Up.ac.za/bitstream/handle/2263/52395/Githuru_Transformative_2015.pdf;seque nce $=1$.

Goldsworthy, J. (2012). Constitutional interpretation in Rosenfeld M. and Sajo A. (eds), The Oxford Handbook of Comparative Constitutional Law (1st ed., pp. 691-705): Oxford University Press.

Gregor, M. J. (1988). Kant's approach to constitutionalism. In Rosenbaum J. R (Ed.), Constitutionalism: The Philosophical Dimension Greenwood Press.

Hailbronne, M. (2016). Overcoming obstacles to North-South dialogue: Transformative constitutionalism and the fight against poverty and institutional failure' 49 Verfassung und Recht in Übersee 253.

Hilary, C. (2002). Writing in rights: Australia and the protection of human rights. 39.

Klare, K. E. (1998). Legal culture and transformative constitutionalism. South African Journal of Human Rights, 14, 146.

Krygier, M. (2012). The rule of law in Michel Rosenfeld and Andras Sajo (eds), The Oxford Handbook of Comparative Constitutional Law (1st ed.): Oxford University Press.

Langa, P. (2006). Transformative constitutionalism 3 Stellenbosch Law Review 351.

Manga, A. M. B. (2002). The road to constitutionalism and democracy in post-colonial Africa: The case of the democratic republic of Congo' (University of South Africa 2002) Retrieved from https://www.peacepalacelibrary.nl/ebooks/files/382583213.pdf.

Mary, D. L. (2003). Who cares about courts? Creating a constituency for judicial independence in Africa (2003) 101 MICH.L. Review, 1622-1630.

Ndemesah, F. (2015). Constitution without constitutionalism: A Malady of African democracies' (WESA, 2015) Retrieved from http://www.wesa.net/-constitution-without-constitutionalism-a-malady-ofafrican-democracies.

Nkumbe, N. N. (2011). The effectiveness of domestic complaint mechanisms in the protection of human rights in Cameroon. Cameroon Journal on Democracy and Human Rights, 5(2), 21.

Prempeh, H. K. (2007). Africa’s “constitutionalism revival. False start or New Dawn 5(3) ICON 469.

Rapatsa, M. (2014). Transformative constitutionalism in South Africa: 20 Years of democracy. Mediterranean Journal of Social Sciences, 5(27), 887.

Robert Post. (1993). Meiklejohn's mistake: Individual autonomy and the reform of public discourse. University of Colorado Law Review, 1109.

Rosenfeld, M. (1994). Modern constitutionalism as interplay between identity and diversity in Michel Rosenfeld (ed), Constitutionalism, Identity, Difference, and Legitimacy: Theoretical Perspectives: Duke University Press.

Sustein, C. R. (1992). On property and constitutionalism comparative constitutionalism: Theoretical perspectives on the role of constitutions in the interplay between identity and diversity. Cardozo Law Review, 14, 907.

Tushnet, M. (2012). Constitution' in Michel Rosenfeld and Andras Sajo (eds), The Oxford Handbook of Comparative Constitutional Law (1st ed., pp. 217-231): Oxford University Press. 
United Nations Development Programme. (2002). Deepening democracy in a fragmented world: Human development report (pp. 56-57): Oxford University Press.

United Nations Development Programme. (2016). Global programme on strengthening the rule of law and human rights for sustainable peace and fostering development (UNDP 2016).

Wehmeier, S. (2000). Oxford advanced learner's dictionary of current English (6th ed.): Oxford University Press.

Wellman, C. (2016). Constitutional rights-what they are and what they ought to be: Springer International Publishing.

Wen-Cheng, C., \& Jiunn-Rong, Y. (2012). Internationalisation of constitutional law. In Michel Rosenfeld and Andras Sajo (Eds), The Oxford Handbook of Comparative Constitutional Law (1st ed., Vol. 1173): Oxford University Press.

Wiechers, M. (2010). The Namibian constitution: Reconciling legality and legitimacy. in Anton Bösl and others (eds), Constitutional Democracy in Namibia. A Critical Analysis after two Decades: Macmillan Education Namibia. 